\title{
Effects of Carbonated Soft Drink on Saliva pH in the Occurrence of Dental Caries
}

\author{
Pengaruh Konsumsi Minuman Bersoda terhadap pH Saliva pada Kejadian Karies Gigi
}

\section{Theofany L. A. Santoso, Dinar A. Wicaksono, Paulina N. Gunawan}

\author{
Program Studi Pendidikan Dokter Gigi Fakultas Kedokteran Universitas Sam Ratulangi \\ Manado, Indonesia \\ E-mail: theofany.listya@gmail.com \\ Received: January 7, 2022; Accepted: February 18, 2022; Published on line: February 19, 2022
}

\begin{abstract}
One of the instantaneous lifestyle can be seen inter alia from the high level of soft drink consumption. Consumption of carbonated soft drinks produces a $\mathrm{pH}$ ranging from 2.4 to 4.07 which is classified as low. $\mathrm{CO}_{2}$ dissolved in carbonated soft drinks is thought to increase acidity, therefore, decrease the $\mathrm{pH}$ of saliva. The continuous decrease in salivary $\mathrm{pH}$ can lead to demineralization of tooth structure which triggers the occurrence of dental caries. This study aimed to determine the effect of soft drink consumption on salivary $\mathrm{pH}$ related to the incidence of dental caries. This was a literature review studi using four databases as follows: Google Scholar, PubMed, ScienceDirect, and ClinicalKey. The keywords were "minuman bersoda" OR "minuman berkarbonasi" AND "pH saliva"; dan "soft drink" OR "carbonated drink" AND "salivary pH". The literatures were selected through inclusion and exclusion criteria and then a critical appraisal was carried out. The results showed that 29 abstracts met the criteria. Full-text articles that met the inclusion and exclusion criteria and be used in this study were 18 articles in total. It was found that there was a change in the degree of acidity after consuming carbonated drinks. In conclusion, carbonated soft drinks can affect the $\mathrm{pH}$ of saliva which triggers the occurrence of dental caries. Keywords: carbonated soft drinks; salivary $\mathrm{pH}$
\end{abstract}

\begin{abstract}
Abstrak: Salah satu gaya hidup masyarakat Indonesia yang serba instan dapat terlihat dari tingginya tingkat konsumsi minuman ringan bersoda. Minuman ringan ini tersedia secara komersil dan bila dikonsumsi menghasilkan $\mathrm{pH}$ berkisar antara 2,4 hingga 4,07 yang tergolong rendah. $\mathrm{CO}_{2}$ yang terlarut dalam minuman bersoda dianggap dapat meningkatkan keasaman dan menurunkan $\mathrm{pH}$ saliva. Penurunan $\mathrm{pH}$ saliva yang terjadi secara terus-menerus dapat menyebabkan demineralisasi struktur gigi yang merupakan awal dari terjadinya karies gigi. Penelitian ini bertujuan untuk mengetahui pengaruh konsumsi minuman bersoda terhadap $\mathrm{pH}$ saliva pada kejadian karies gigi. Jenis penelitian ialah suatu literature review, yang menggunakan database Google Scholar, PubMed, ScienceDirect, dan ClinicalKey serta kata kunci "minuman bersoda" $O R$ "minuman berkarbonasi" AND "pH saliva"; dan "soft drink" OR "carbonated drink" AND "salivary $p H$ ". Literatur diseleksi melalui kriteria inklusi dan eksklusi serta dilakukan critical appraisal. Hasil penelitian mendapatkan jumlah literatur sebanyak 29 abstrak yang memenuhi kriteria sedangkan artikel fulltext yang memenuhi kriteria inklusi dan eksklusi sebanyak 18 artikel. Hasil kajian mendapatkan terjadi perubahan derajat keasaman setelah mengonsumsi minuman ringan bersoda. Simpulan penelitian ini ialah minuman bersoda dapat memengaruhi $\mathrm{pH}$ saliva yang selanjutnya memicu terjadinya karies gigi.
\end{abstract}

Kata kunci: minuman bersoda; $\mathrm{pH}$ saliva

\section{PENDAHULUAN}

Masyarakat saat ini umumnya memiliki gaya hidup serba instan dilihat dari tingginya tingkat konsumsi minuman ringan di 
Indonesia. Minuman ringan yang umumnya bersifat asam ini beredar luas di kalangan masyarakat, baik masyarakat menengah ke bawah maupun masyarakat menengah ke atas. Salah satu minuman ringan yang banyak digemari masyarakat ialah minuman ringan yang mengandung asam bikarbonat, atau biasa dikenal sebagai minuman berkarbonasi atau minuman bersoda. Popularitas minuman bersoda ini pun terus meningkat di Indonesia dari tahun 2010 ke 2014, dengan peningkatan konsumsi minuman bersoda mencapai 85,6\%. Berdasarkan Badan Penelitian dan Pengembangan Kesehatan (Balitbangkes) pada tahun 2014, survei konsumsi makanan individu menunjukkan data konsumsi minuman bersoda sebanyak 2,4 $\mathrm{ml}$ /orang/hari. Kelompok usia 13-18 tahun merupakan konsumen terbesar yaitu sebesar 4,7 ml/orang/hari. ${ }^{1-3}$

Minuman bersoda yang dikonsumsi dan tersedia secara komersial memiliki $\mathrm{pH}$ berkisar antara 2,4 hingga 4,07 yang tergolong rendah. Minuman dengan $\mathrm{pH}$ rendah berpotensi merusak gigi. $\mathrm{CO}_{2}$ terlarut dalam minuman bersoda dianggap dapat meningkatkan keasaman dan menurunkan $\mathrm{pH}$ saliva. ${ }^{1}$ Saliva memiliki derajat keasaman atau $\mathrm{pH}$ pada keadaan normal yaitu 5,6-7,0 dan dapat berubah tiap saat dengan rerata $\mathrm{pH}$ 6,7. Gigi mengalami demineralisasi dan remineralisasi. Proses demineralisasi menjadi lebih cepat daripada remineralisasi ketika terjadi penurunan $\mathrm{pH}$ saliva di bawah 5,5. Penurunan $\mathrm{pH}$ saliva yang terjadi secara terus-menerus dapat menyebabkan demineralisasi struktur gigi yang merupakan awal dari terjadinya karies gigi. ${ }^{4}$

Prevalensi kejadian karies gigi yang tinggi dan minuman bersoda yang masih menjadi kegemaran masyarakat menunjukkan kurangnya kepedulian masyarakat akan kesehatan gigi dan mulut. Beredarnya minuman bersoda dipasaran namun kurangnya pengetahuan akan pengaruh mengonsumsi minuman tersebut terhadap gigi dan mulut dapat menjadi masalah di masa mendatang. Oleh karena itu, penulis terdorong untuk mengangkat topik mengenai pengaruh konsumsi minuman bersoda terhadap $\mathrm{pH}$ saliva pada kejadian karies gigi melalui suatu penelitian literature review.

\section{METODE PENELITIAN}

Penelitian ini merupakan suatu literature review yang menggunakan empat database yaitu Google Scholar, PubMed, ScienceDirect, dan ClinicalKey dengan kata kunci "minuman bersoda" $O R$ "minuman berkarbonasi" AND "pH saliva"; dan "soft drink" OR "carbonated drink" AND "salivary $p H$ ". Literatur disaring berdasarkan kriteria inklusi dan eksklusi kemudian dilakukan critical appraisal menggunakan The Joanna Briggs Institute (JBI) Critical Appraisal.

\section{HASIL PENELITIAN}

Artikel yang telah diidentifikasi diunduh dan dilakukan eliminasi untuk artikel yang terduplikat sehingga jumlah yang didapat sebanyak 26 abstrak yang memenuhi kriteria. Artikel fulltext yang memenuhi kriteria inklusi dan eksklusi sebanyak 18 artikel. Lima dari delapan belas artikel menggunakan desain penelitian crosssectional, tujuh artikel menggunakan desain penelitian quasi-experimental, tiga artikel menggunakan randomized controlled trial, dua cohort (cross over), dan satu artikel menggunakan case control. Tabel 1 pada halaman 72-74 menggambarkan hasil ulasan artikel yang telah dilakukan.

\section{BAHASAN}

Berdasarkan penelitian dari hasil literatur yang di-review, umumnya responden mengalami perubahan $\mathrm{pH}$ saliva setelah mengonsumsi minuman bersoda. Penelitian oleh Andriyani, ${ }^{5}$ Astuti, ${ }^{8}$ dan Larosa ${ }^{9}$ menyatakan adanya pengaruh minuman bersoda terhadap $\mathrm{pH}$ saliva, kemungkinan dikarenakan kapasitas cairan buffer saliva tidak mampu menahan turunnya $\mathrm{pH}$. Minuman bersoda yang dikonsumsi mengandung gula, karbon dioksida, asam askorbat dan asam sitrat. Minuman bersoda bersifat asam dan memiliki pH 3,0 atau lebih rendah dan dapat mengakibatkan erosi pada gigi pada waktu kritis yaitu pada menit pertama setelah terpapar.

Angka pH saliva dapat dipengaruhi oleh 
frekuensi mengonsumsi minuman bersoda karena kandungan dalam konsentrasi tinggi terdapat didalamnnya. Hal ini sesuai dengan penelitian oleh Maulina et $\mathrm{al}^{6}$ dan Fitriati et $\mathrm{al}^{7}$ yaitu semakin banyak frekuensi minum minuman bersoda, $\mathrm{pH}$ saliva semakin asam. Frekuensi konsumsi minuman bersoda berisiko menyebabkan $\mathrm{pH}$ saliva berada pada kondisi asam sehingga menyebabkan demineralisasi gigi. Semakin tinggi tingkat frekuensi sesorang mengonsumsi minuman bersoda dalam satu hari dapat mengubah $\mathrm{pH}$ saliva menjadi asam dan keadaan ini mempercepat terjadinya karies gigi yang merupakan rusaknya struktur gigi dan penyakit infeksi yang menyebabkan gigi berlubang. Lubang pada gigi disebabkan oleh bakteri penghasil asam karena adanya reaksi fermentasi karbohidrat. Asam yang diproduksi menyebabkan mineral gigi menjadi sensitif pada $\mathrm{pH}$ yang rendah. $\mathrm{pH}$ yang turun dibawah 5,5 menyebabkan proses demineralisasi lebih cepat dari proses remineralisasi. ${ }^{7}$

Berbeda dengan laporan dari Asriawal dan Angki ${ }^{10}$ yang meneliti korelasi antara frekuensi minum soft drink dengan $\mathrm{pH}$ saliva yang menunjukkan adanya korelasi yang tidak bermakna. Perbedaan ini dapat terjadi dikarenakan perbedaan usia sampel, kondisi rongga mulut, kebiasaan setelah mengonsumsi soft drink, dan tingkat pengetahuan tentang kesehatan gigi yang berbeda pada penelitian.

Pola konsumsi minuman ringan menjadi perhatian dalam bidang kesehatan karena dapat memengaruhi kondisi kesehatan rongga mulut terutama kejadian karies gigi. Salah satu minuman ringan yang digemari masyarakat ialah teh. Menurut pengamatan Wiradona et al, ${ }^{10}$ remaja terutama mahasiswa sering mengonsumsi minuman teh, baik teh bersoda maupun teh tidak bersoda. Penelitian tersebut mendapatkan bahwa $\mathrm{pH}$ saliva sesudah mengonsumsi teh bersoda mengalami penurunan yang lebih banyak dibandingkan dengan penurunan sesudah mengonsumsi teh tidak bersoda. Teh tidak bersoda mengalami penurunan karena mengandung gula. Penurunan $\mathrm{pH}$ saliva sesudah mengonsumsi teh bersoda lebih besar karena kandungan dalam teh bersoda yang cenderung asam yaitu gula, $\mathrm{CO}_{2}$, asam sitrat dan asam askorbat. Rasa asam pada teh bersoda dapat memengaruhi $\mathrm{pH}$ saliva karena $\mathrm{pH}$ saliva dapat pula dipengaruhi secara kimiawi yaitu rangsangan rasa asam dan manis. Adanya paparan gula dapat menyebabkan bakteri asidogenik dengan cepat melakukan metabolisme karbohidrat sehingga menghasilkan asam. ${ }^{10}$

Purwanti ${ }^{11}$ juga meneliti efek minuman berkarbonasi pada $\mathrm{pH}$ saliva dan membandingkannya dengan minuman rasa jeruk. Kedua jenis minuman tersebut menghasilkan penurunan $\mathrm{pH}$ saliva segera setelah dikonsumsi. Menit ke-5 setelah mengonsumsi produk didapati bahwa $\mathrm{pH}$ saliva kelompok subjek minuman berkarbonasi mengalami peningkatan namun masih tergolong asam dan $\mathrm{pH}$ saliva kelompok subjek minuman rasa jeruk sudah mulai kembali normal. Hal ini dikarenakan $\mathrm{pH}$ minuman berkarbonasi yang digunakan pada penelitian ini 2,4 sedangkan $\mathrm{pH}$ minuman rasa jeruk 3,4, sehingga butuh waktu lebih lama untuk minuman berkarbonasi mengembalikan $\mathrm{pH}$ saliva ke normal. Asam fosfor pada minuman berkarbonasi lebih lambat dinetralisir dibandingkan denga asam sitrat yang ada di dalam minuman rasa jeruk. ${ }^{11}$

Perubahan pada $\mathrm{pH}$ saliva ini sesuai dengan kurva Stephan yang menyatakan bahwa $\mathrm{pH}$ akan mulai kembali normal dalam waktu 10-30 menit. Lamanya $\mathrm{pH}$ kembali ke batas normal dapat disebabkan karena masih berlangsungnya metabolisme sisa zat gula yang diabsorbsi oleh biofilm. Kebiasaan minum minuman ringan pada individu yang rentan karies juga dapat menghambat kembalinya $\mathrm{pH}$ saliva ke batas normal karena mengalami penurunan yang lebih rendah daripada individu yang resisten karies. Baik minuman rasa jeruk dan minuman berkarbonasi keduanya merupakan minuman ringan, namun didapati bahwa rerata penurunan $\mathrm{pH}$ pada subjek minuman berkarbonasi cenderung lebih tinggi dibandingkan dengan minuman rasa jeruk. ${ }^{11}$ Selaras dengan penelitian oleh Pratha ${ }^{12}$ yang membandingkan efek minuman berkarbonasi dengan minuman berenergi terhadap 
$\mathrm{pH}$ saliva yaitu tidak terdapat perubahan bermakna setelah mengonsumsi minuman berenergi, namun $\mathrm{pH}$ menjadi asam setelah mengonsumsi minuman berkarbonasi. Saat mengonsumsi minuman berenergi, setelah terjadi penurunan $\mathrm{pH}$ saliva dimenit ke-5, pada menit ke-10 sampai ke-15 $\mathrm{pH}$ meningkat hampir mencapai baseline.

Penelitian Hirani et $\mathrm{al}^{18}$ dan Pachori et al ${ }^{19}$ juga mendapatkan penurunan $\mathrm{pH}$ saliva setelah mengonsumsi minuman berkarbonasi. Saliva memiliki potensi untuk mempertahankan $\mathrm{pH}$ pada tingkat normal namun konsumsi makanan dan minuman menyebabkan penurunan $\mathrm{pH}$ mendekati batas kritis yaitu, 5,5 di mana demineralisasi jaringan gigi dapat terjadi. Penurunan $\mathrm{pH}$ saliva setelah konsumsi minuman berkarbonasi dikaitkan dengan kandungan asamnya dan penurunan $\mathrm{pH}$ ini dipertahankan oleh kandungan lain termasuk persentase karbohidrat. Penurunan ini tidak hanya meningkatkan kejadian karies tetapi apabila bertahan lama maka akan terjadi lesi yang erosif. Faktor pejamu yang berbeda, seperti frekuensi konsumsi dan pola pengunyahan dapat mendukung potensi asidogenik.

Potensi asidogenik dapat dikurangi dengan memodifikasi minuman berkarbonasi dengan kalsium fosfat dan natrium fluoride seperti pada penelitian Sardana et al. ${ }^{22}$ Semua kelompok yang diuji dalam penelitian ini mengalami penurunan $\mathrm{pH}$ plak, dengan pemulihan bertahap pada $\mathrm{pH}$ selama 30 menit. Namun, penurunan $\mathrm{pH}$ secara bermakna lebih besar ketika subjek menggunakan minuman asli yang tidak dimodifikasi, meskipun memiliki konsentrasi gula yang sama. Konsentrasi fluoride yang dibutuhkan mungkin lebih untuk meniadakan respons asidogenik dari minuman ini, yang mungkin dapat menjadi toksik jika terus menerus terpapar minuman ini.

Minuman dianggap dapat dibersihkan dari rongga mulut dengan cepat, tetapi sebaliknya minuman mempertahankan tingkat $\mathrm{pH}$ rendah untuk jangka waktu yang lebih lama. Karbohidrat yang dikonsumsi dalam bentuk cair biasanya tidak berada di mulut dalam waktu yang lama, tetapi jika sering dikonsumsi sepanjang hari, kemung- kinan mengembangkan karies gigi meningkat. Jika gigi terus-menerus terkena minuman manis, asam yang dihasilkan oleh bakteri tetap berada di rongga mulut untuk waktu yang lebih lama sehingga menyebabkan karies gigi dan erosi. Pada penelitian Hans et $\mathrm{al}^{16}$ ditemukan bahwa perbedaan $\mathrm{pH}$ saliva rata-rata pada awal dan pada interval waktu yang berbeda setelah konsumsi pepsi, minuman buah, kopi, dan susu manis ditemukan signifikan secara statistik.

Penelitian oleh Sudeep et $\mathrm{al}^{15}$ menunjukkan perubahan $\mathrm{pH}$ saliva yang maksimum setelah konsumsi jus apel berkarbonasi yang merupakan minuman apel bersoda. Penurunan ini dapat dikaitkan dengan $\mathrm{pH}$ intrinsik yang relatif lebih rendah dari jus buah yang tersedia secara komersial. Dalam hal ini dapat digambarkan bahwa tingkat penurunan $\mathrm{pH}$ minuman apel bersoda $>$ jus apel (nektar) $>$ minuman apel (bebas gula).

Minuman yang beredar memiliki keasaman jauh di bawah $\mathrm{pH}$ kritis email dan minuman berbasis soda memiliki pH lebih rendah (lebih asam) dan menyebabkan lebih banyak email larut. Hal ini sejalan dengan penelitian Nyan et $\mathrm{al}^{14}$ dan Tenuta et $\mathrm{al}^{21}$ yang menyatakan $\mathrm{pH}$ minuman memengaruhi potensi erosif minuman saat dikonsumsi. Semakin asam minuman, semakin erosif sifatnya. Beberapa penelitian menyatakan bahwa tidak hanya $\mathrm{pH}$ minuman tetapi keasaman yang dapat dititrasi yaitu kapasitas untuk mempertahankan $\mathrm{pH}$ rendah memengaruhi potensi erosifnya. Penelitian De Lima et $\mathrm{al}^{20}$ mendapati penurunan bermakna pada $\mathrm{pH}$ lingkungan mulut setelah konsumsi minuman ringan, yang dapat menyebabkan hilangnya keseimbangan mineral struktur gigi segera setelah konsumsi. Variabel yang juga penting dalam potensi erosif minuman ringan ialah kapasitas buffer-nya. Semakin besar kappasitas buffer-nya, semakin lama waktu saliva untuk menetralkan asam.

Secara keseluruhan, literatur-literatur yang telah di-review membuktikan bahwa terdapat pengaruh mengonsumsi minuman bersoda atau berkarbonasi terhdap perubahan $\mathrm{pH}$ saliva. Penelitian literature review 
ini masih memiliki banyak kekurangan yang tidak bisa dikendalikan oleh peneliti karena data yang diambil merupakan data sekunder yang berasal dari penelitian yang telah dilakukan sebelumnya. Kekurangan tersebut diantaranya ialah perbedaan jumlah sampel, perlakuan yang berbeda-beda dan jenis minuman bersoda yang digunakan berbeda sehingga dapat menyebabkan terjadinya bias. Proses pencarian artikel yang terbatas karena adanya beberapa artikel yang memerlukan akses dan juga berbayar.

\section{SIMPULAN}

Terdapat pengaruh konsumsi minuman bersoda terhadap $\mathrm{pH}$ saliva yang dapat memicu kejadian karies gigi.

\section{Konflik Kepentingan}

Penulis menyatakan tidak terdapat konflik kepentingan dalam studi ini.

\section{DAFTAR PUSTAKA}

1. Hutabarat KK. Gambaran $\mathrm{pH}$ saliva terhadap konsumsi minuman bersoda dan tidak bersoda pada siswa/i Sekolah Menengah Pertama (SMP) Negeri 26 Medan. Politeknik Kesehatan RI Medan; 2019. Available from: http://repo.poltekkesmedan.ac.id/jspui/handle/123456789/8 14

2. Mutaqin ZZ. Dinamika aspek kesehatan dan ekonomi dalam kebijakan pengendalian minuman berkarbonasi di Indonesia. Quality. 2018;12(1):26-37.

3. Litbangkes Kemenkes RI. Studi Diet Total: Survei Konsumsi Makanan Individu. 2014;43.

4. Mulyanti R, Karyadi E, Yuletnawati SE. Perbedaan konsumsi minuman bersoda dan isotonik terhadap peningkatan plak gigi mahasiswa Fakultas Kedokteran Gigi Universitas Muhammadiyah Surakarta Angkatan 2014 [Skripsi]. Surakarta: Universitas Muhammadiyah Surakarta; 2015. Available from: http://eprints.ums.ac.id/39404/

5. Andriyani D. Relationship of Consuming softdrink $\mathrm{nn} \mathrm{pH}$ saliva acidity in students of SMAN 13 Bandar Lampung in 2020. J Kesehat gigi [Internet]. 2020;8(1):10-5. Available from: http: //ejournal.poltekkes-smg.ac.id/ojs/ index.php/jkg/article/view/6530

6. Maulina N, Sawitri H, Millizia A. Hubungan konsumsi minuman ringan dengan $\mathrm{pH}$ saliva pada mahasiswa Program Studi Kedokteran Fakultas Kedokteran Universitas Malikussaleh Tahun 2019. Averrous. 2019;6(2):61-7.

7. Fitriati N, Hernawan AD, Trisnawati E. Perilaku konsumsi minuman ringan (softdrink) dan $\mathrm{pH}$. Unnes J Public Heal. 2017;6(2):113-21

8. Astuti NPW. Purnami T, Kusuma Putra CGA. Minuman ringan berkarbonasi dapat meningkatkan keasaman rongga mulut. Interdental. 2018;14(1):9-12.

9. Larosa N. Pengaruh meminum softdrink terhadap $\mathrm{pH}$ saliva pada siswa/siswi kelas VIII-A SMP TD Pardede Foundation Kecamatan Sunggal Kabupaten Deli Serdang. 2019. Available from: http://ecampus.poltekkes-medan.ac.id/ xmlui/handle/123456789/4811

10. Wiradona I, Sadimin, Fitri SH. Mengkonsumsi Minuman Teh Bersoda dan Teh Tidak Bersoda terhadap pH Saliva. J Kesehat Gigi [Internet]. 2017;04(2):27-32. Available from: http://ejournal. poltekkes-smg.ac.id/ojs/index.php/jkg/ article/view/3201

11. Purwanti LK. Efek konsumsi minuman berkarbonasi dan minuman rasa jeruk terhadap $\mathrm{pH}$ saliva pada mahasiswa PSPDG Fakultas Kedokteran Universitas Udayana. Bali Dental Journal. 2018;2(1):37-43.

12. Pratha AA, Prabakar J. Comparing the effect of carbonated and energy drinks on Salivary $\mathrm{pH}$ - in vivo randomized controlled trial. RJPT. 2019;12(10):6-10.

13. Asriawal A, Angky J. Hubungan frekuensi minum soft drink (bersoda) terhadap $\mathrm{pH}$ saliva dan angka DMF-T pada mahasiswa D-IV Jurusan Keperawatan Gigi Poltekkes Makassar. Media Kesehatan Gigi. 2019;18(2):22-31.

14. Nyan M, T Win A, Yan AT, Yin MSK. Phyo $\mathrm{T}$, Oo $\mathrm{Y}$, et al. Acidity and effect on enamel on enamel dissolution of ten commonly consumed soft drinks /beverages in Myanmar. Myanmar Dental Journal. 2017;1(24):27-30.

15. Sudeep CB, Sequeira PS, Jain J, Jain V, Maliyil M. Effects on $\mathrm{pH}$ value of saliva following intake of three beverages containing apple juice - a double blind 
cross- over study. National Journal of Medical and Dental Research (NJMDR). 2013;1(4):18-23.

16. Hans R, Thomas S, Garla B, Dagli RJ, Hans MK. Effect of various sugary beverages on salivary $\mathrm{pH}$, flow rate, and oral clearance rate amongst adults. Scientifica (Cairo). 2016;2016: 5027283. Doi: $10.1155 / 2016 / 5027283$.

17. Goel I, Navit S, Mayall SS, Rallan M, Navit P, Chandra S. Effects of carbonated drink $\&$ fruit juice on salivary $\mathrm{pH}$ of children: an in vivo study. International Journal of Scientific Study. 2013;1(3):60-7.

18. Hirani H, Iqbal N, Bijarani AN, Hashmi UP, Khurram S, Baig NJ. Effects of different beverages on salivary ph and time taken by saliva to regain normal $\mathrm{pH}$ among teenagers. J Pharm Res Int. 2021;33 (May):140-4.

19. Pachori A, Kambalimath H, Maran S, Niranjan B, Bhambhani G, Malhotra G. Evaluation of changes in salivary $\mathrm{pH}$ after intake of different eatables and beve- rages in children at different time intervals. Int J Clin Pediatr Dent [Internet]. 2018;11(3):177-82. Available from: https://www.ncbi.nlm.nih.gov/ pmc/articles/PMC6102436/pdf/ijcpd11-177.pdf

20. De Lima Almenara OCP, Rebouças AG, Cavalli AM, Durlacher MM, Oliveira AMG, Flório FM, et al. Influence of soft drink intake on the salivary $\mathrm{pH}$ of schoolchildren. Pesqui Bras Odontopediatria Clin Integr. 2016;16(1):24955.

21. Tenuta LMA, Fernández CE, Brandão ACS, Cury JA. Titratable acidity of beverages influences salivary $\mathrm{pH}$ recovery. Braz Oral Res. 2015;29(1):1-6.

22. Sardana V. Balappanavar AY, Patil GB, Kulkarni N, Sagari SG, Gupta KD. Impact of a modified carbonated beverage on human dental plaque and salivary $\mathrm{pH}$ : an in vivo study. J Indian Soc Pedod Prev Dent. 2012;30(1):712. Doi: $10.4103 / 0970-4388.95563$ 
72 e-GiGi, Volume 10 Nomor 1, Januari-Juni 2022, hlm. 66-74

Tabel 1. Hasil kajian artikel

\begin{tabular}{|c|c|c|c|c|c|}
\hline No & $\begin{array}{l}\text { Peneliti/ } \\
\text { Tahun }\end{array}$ & $\begin{array}{l}\text { Lokasi } \\
\text { Peneliti- } \\
\text { an }\end{array}$ & Judul Penelitian & $\begin{array}{c}\text { Desain } \\
\text { Penelitian }\end{array}$ & Rangkuman Hasil Penelitian \\
\hline 1 & $\begin{array}{l}\text { Andriyani/ } \\
2020^{5}\end{array}$ & $\begin{array}{l}\text { Bandar } \\
\text { Lampung } \\
\text { Indonesia }\end{array}$ & $\begin{array}{l}\text { Relationship of consuming } \\
\text { softdrink nn pH saliva acidity } \\
\text { in students of SMAN } 13 \\
\text { Bandar Lampung in } 2020\end{array}$ & Cross sectional & $\begin{array}{l}\text { Ada pengaruh minuman softdrink } \\
\text { dengan penurunan } \mathrm{pH} \text { saliva pada } \\
\text { siswa/i SMAN } 13 \mathrm{Bandar} \text { Lampung. }\end{array}$ \\
\hline 2 & $\begin{array}{l}\text { Maulina et } \\
\text { al } / 2020^{6}\end{array}$ & $\begin{array}{l}\text { Aceh, } \\
\text { Indonesia }\end{array}$ & $\begin{array}{l}\text { Hubungan konsumsi } \\
\text { minuman ringan dengan } \mathrm{pH} \\
\text { saliva pada mahasiswa } \\
\text { Program Studi Kedokteran } \\
\text { Fakultas Kedokteran } \\
\text { Universitas Malikussaleh } \\
\text { Tahun } 2019\end{array}$ & Cross sectional & $\begin{array}{l}\text { Terdapat hubungan yang bermakna } \\
\text { antara konsumsi minuman ringan } \\
\text { dengan pH saliva pada mahasiswa } \\
\text { Prodi Kedokteran FK Unimal. }\end{array}$ \\
\hline 3 & $\begin{array}{l}\text { Fitriati et } \\
\text { al } / 2017^{7}\end{array}$ & $\begin{array}{l}\text { Ponti- } \\
\text { anak } \\
\text { Timur, } \\
\text { Indonesia }\end{array}$ & $\begin{array}{l}\text { Perilaku konsumsi minuman } \\
\text { ringan (softdrink) dan } \mathrm{pH} \\
\text { saliva dengan kejadian karies } \\
\text { gigi }\end{array}$ & Cross sectional & $\begin{array}{l}\text { Terdapat hubungan yang bermakna } \\
\text { antara pH saliva dengan kejadian } \\
\text { karies gigi. } \\
\text { Perilaku konsumsi minuman ringan } \\
\text { (soft drink) dapat memengaruhi } \\
\text { kejadian karies gigi karena adanya } \\
\text { hubungan yang signifikan dengan pH } \\
\text { saliva. }\end{array}$ \\
\hline 4 & $\begin{array}{l}\text { Astuti et } \\
\text { al } / 2018^{8}\end{array}$ & $\begin{array}{l}\text { Denpasar } \\
\text { Indonesia }\end{array}$ & $\begin{array}{l}\text { Minuman ringan berkarbonasi } \\
\text { dapat meningkatkan } \\
\text { keasaman rongga mulut }\end{array}$ & $\begin{array}{l}\text { Quasi- } \\
\text { experimental }\end{array}$ & $\begin{array}{l}\text { Terdapat perbedaan yang signifikan } \\
\text { antara } \mathrm{pH} \text { saliva sebelum dan sesu- } \\
\text { dah mengonsumsi minuman ringan } \\
\text { berkarbonasi akibat turunnya pH } \\
\text { tidak mampu ditahan oleh kapasitas } \\
\text { cairan buffer saliva sehingga dapat } \\
\text { disimpulkan bahwa minuman ringan } \\
\text { berkarbonasi dapat meningkatkan } \\
\text { keasaman rongga mulut. }\end{array}$ \\
\hline 5 & $\begin{array}{l}\text { Larosa/ } \\
2019^{9}\end{array}$ & $\begin{array}{l}\text { Deli } \\
\text { Serdang, } \\
\text { Indonesia }\end{array}$ & $\begin{array}{l}\text { Pengaruh meminum soft- } \\
\text { drink terhadap penurunan pH } \\
\text { saliva pada siswa/siswi Kelas } \\
\text { VIII-A SMP TD Pardede } \\
\text { Foundation Kecamatan } \\
\text { Sunggal Kabupaten Deli } \\
\text { Serdang Tahun } 2019\end{array}$ & $\begin{array}{l}\text { Quasi- } \\
\text { experimental }\end{array}$ & $\begin{array}{l}\text { Berdasarkan hasil uji Paired t-test } \\
0,00<0,05 \text { disimpulkan bahwa me- } \\
\text { minum softdrink dapat memengaruhi } \\
\text { penurunan pH saliva. }\end{array}$ \\
\hline 6 & $\begin{array}{l}\text { Wiradona et } \\
\mathrm{al} / 2017^{10}\end{array}$ & $\begin{array}{l}\text { Sema- } \\
\text { rang, } \\
\text { Indonesia }\end{array}$ & $\begin{array}{l}\text { Mengonsumsi minuman teh } \\
\text { bersoda dan teh tidak bersoda } \\
\text { terhadap pH saliva }\end{array}$ & $\begin{array}{l}\text { Quasi- } \\
\text { experimental }\end{array}$ & $\begin{array}{l}\text { Terdapat perbedaan } \mathrm{pH} \text { saliva antara } \\
\text { minum minuman teh bersoda dengan } \\
\text { teh tidak bersoda karena penurunan } \\
\text { pH saliva yang lebih besar saat mi- } \\
\text { num minuman teh bersoda daripada } \\
\text { minum minuman teh tidak bersoda. }\end{array}$ \\
\hline 7 & $\begin{array}{l}\text { Purwanti/ } \\
2018^{11}\end{array}$ & $\begin{array}{l}\text { Bali, } \\
\text { Indonesia }\end{array}$ & $\begin{array}{l}\text { Efek konsumsi minuman } \\
\text { berkarbonasi dan minuman } \\
\text { rasa jeruk terhadap pH saliva } \\
\text { pada mahasiswa PSPDG } \\
\text { Fakultas Kedokteran } \\
\text { Universitas Udayana }\end{array}$ & $\begin{array}{l}\text { Quasi- } \\
\text { experimental }\end{array}$ & $\begin{array}{l}\text { Rerata penurunan pH saliva pada } \\
\text { kelompok yang mengonsumsi mi- } \\
\text { numan berkarbonasi lebih tinggi } \\
\text { dibandingkan kelompok yang memi- } \\
\text { num minuman rasa jeruk. }\end{array}$ \\
\hline 8 & $\begin{array}{l}\text { Pratha dan } \\
\text { Prabakar/ } \\
2019^{12}\end{array}$ & $\begin{array}{l}\text { Chennai, } \\
\text { India }\end{array}$ & $\begin{array}{l}\text { Comparing the effect of } \\
\text { carbonated and energy drinks } \\
\text { on salivary pH- } \\
\text { In Vivo Randomized } \\
\text { controlled trial }\end{array}$ & $\begin{array}{l}\text { Randomized } \\
\text { controlled trial }\end{array}$ & $\begin{array}{l}\text { Tidak ada perubahan } \mathrm{pH} \text { yang ber- } \\
\text { makna setelah mengonsumsi air } \\
\text { mineral Bisleri tetapi pH menjadi } \\
\text { lebih asam setelah mengonsumsi } \\
\text { minuman berkarbonasi. Lebih baik } \\
\text { mengonsumsi minuman berenergi } \\
\text { daripada minuman berkarbonasi. }\end{array}$ \\
\hline
\end{tabular}




\begin{tabular}{|c|c|c|c|c|c|}
\hline 9 & $\begin{array}{l}\text { Arisawal } \\
\text { dan Angki/ } \\
2019^{13}\end{array}$ & Makassar & $\begin{array}{l}\text { Hubungan frekuensi minum } \\
\text { soft drink (bersoda) terhadap } \\
\text { pH saliva dan angka DMF-T } \\
\text { pada mahasiswa D-IV } \\
\text { Jurusan Keperawatan Gigi } \\
\text { Poltekkes Makassar }\end{array}$ & Cross sectional & $\begin{array}{l}\text { Hasil uji kolerasi memperoleh nilai } \\
\text { kolerasi } 0,222 \text { dengan nilai sign } 0,169 \\
>0,05 \text { menunjukkan korelasi yang } \\
\text { tidak bermakna (tidak ada hubungan) } \\
\text { antara frekuensi minum soft drink } \\
\text { dengan angka DMF-T dimana ketika } \\
\text { frekuensi minum soft drink meingkat } \\
\text { hal itu tidak berhubungan dengan } \\
\text { angka DMF-T }\end{array}$ \\
\hline 10 & $\begin{array}{l}\text { Nyan et } \\
\mathrm{al} / 2017^{14}\end{array}$ & Myanmar & $\begin{array}{l}\text { Acidity And effect on enamel } \\
\text { dissolution of ten commonly } \\
\text { consumed soft } \\
\text { drinks/beverages in Myanmar }\end{array}$ & $\begin{array}{l}\text { Randomized } \\
\text { controlled trial }\end{array}$ & $\begin{array}{l}\text { Minuman ringan yang umum dikon- } \\
\text { sumsi di Myanmar berbahaya bagi } \\
\text { kesehatan gigi dan minuman ringan } \\
\text { dengan pH rendah menyebabkan } \\
\text { lebih banyak kelarutan email. }\end{array}$ \\
\hline 11 & $\begin{array}{l}\text { Sudeep et } \\
\mathrm{al} / 2013^{15}\end{array}$ & India & $\begin{array}{l}\text { Effects on pH value of saliva } \\
\text { following intake of three } \\
\text { beverages containing apple } \\
\text { juice - a double blind cross- } \\
\text { over study }\end{array}$ & $\begin{array}{l}\text { Cohort (cross } \\
\text { over) }\end{array}$ & $\begin{array}{l}\text { Jus Apel yang merupakan minuman } \\
\text { berkarbonasi menunjukkan penu- } \\
\text { runan maksimum pH saliva bila } \\
\text { dibandingkan dengan dua minuman } \\
\text { uji lainnya. Hasil penelitian menun- } \\
\text { jukkan bahwa ketiga bentuk minum- } \\
\text { an buah yang tersedia menyebabkan } \\
\text { penurunan pH saliva yang bermakna. }\end{array}$ \\
\hline 12 & $\begin{array}{l}\text { Hans et } \\
\text { al/2016 }\end{array}$ & India & $\begin{array}{l}\text { Effect of various sugary } \\
\text { beverages on salivary ph, } \\
\text { flow rate, and oral clearance } \\
\text { rate amongst adults }\end{array}$ & $\begin{array}{l}\text { Quasi- } \\
\text { experimental }\end{array}$ & $\begin{array}{l}\text { pH saliva menurun untuk semua } \\
\text { minuman segera setelah dikonsumsi } \\
\text { dan laju aliran saliva meningkat } \\
\text { setelah dikonsumsi. Meskipun dite- } \\
\text { mukan bahwa cairan dibersihkan } \\
\text { dengan cepat dari rongga mulut, } \\
\text { mereka memiliki potensi kariogenik } \\
\text { dan erosif yang signifikan. }\end{array}$ \\
\hline 13 & $\begin{array}{l}\text { Goel et } \\
\mathrm{al} / 2013^{17}\end{array}$ & India & $\begin{array}{l}\text { Effects of carbonated drink \& } \\
\text { fruit juice on salivary ph of } \\
\text { children: an in vivo study }\end{array}$ & $\begin{array}{l}\text { Quasi- } \\
\text { experimental }\end{array}$ & $\begin{array}{l}\text { Terjadi penurunan } \mathrm{pH} \text { saliva setelah } \\
\text { konsumsi kedua jenis minuman } \\
\text { tersebut. Ada penurunan pH saliva } \\
\text { yang lebih tinggi dalam kasus jus } \\
\text { buah jika dibandingkan dengan } \\
\text { minuman berkarbonasi. Konsumsi } \\
\text { minuman seperti itu secara teratur } \\
\text { harus dihindari }\end{array}$ \\
\hline 14 & $\begin{array}{l}\text { Hirani et } \\
\mathrm{al} / 2021^{18}\end{array}$ & Pakistan & $\begin{array}{l}\text { Effects of different beverages } \\
\text { on salivary ph and time taken } \\
\text { by saliva to regain normal ph } \\
\text { among teenagers }\end{array}$ & Cross sectional & $\begin{array}{l}\text { Tidak ada perbedaan pH saliva } \\
\text { setelah mengkonsumsi susu, susu } \\
\text { dengan tambahan gula, minuman } \\
\text { berkarbonasi dan jus lemon segar } \\
\text { setelah } 15 \text { menit. Setelah } 2 \text { jam pH } \\
\text { saliva kembali ke nilai normal. }\end{array}$ \\
\hline 15 & $\begin{array}{l}\text { Pachori et } \\
\text { al/2018 }\end{array}$ & India & $\begin{array}{l}\text { Evaluation of changes in } \\
\text { salivary pH after intake of } \\
\text { different eatables and } \\
\text { beverages in children at } \\
\text { different time intervals }\end{array}$ & Case control & $\begin{array}{l}\text { Penurunan maksimum terlihat pada } \\
\text { minuman bersoda jika dibandingkan } \\
\text { dengan jus buah. Peningkatan pH } \\
\text { maksimum diamati pada biscuit krim } \\
\text { dengan } 7,63 \pm 0,20 \text {. Diamati bahwa } \\
\text { pada semua kelompok, pH secara } \\
\text { bertahap kembali mendekati tingkat } \\
\text { normal karena mekanisme buffer } \\
\text { saliva. }\end{array}$ \\
\hline 16 & $\begin{array}{l}\text { de Lima } \\
\text { Almenara et } \\
\text { al } / 2016^{20}\end{array}$ & Brazil & $\begin{array}{l}\text { Influence of soft drink intake } \\
\text { on the salivary pH of } \\
\text { schoolchildren }\end{array}$ & $\begin{array}{l}\text { Quasi } \\
\text { experimental }\end{array}$ & $\begin{array}{l}\text { Asupan Coca-Cola (minuman ber- } \\
\text { soda pada penelitian ini) menyebab- } \\
\text { kan penurunan pH saliva yang } \\
\text { bermakna, namun tidak mencapai pH } \\
\text { kritis untuk demineralisasi email. }\end{array}$ \\
\hline
\end{tabular}


74 e-GiGi, Volume 10 Nomor 1, Januari-Juni 2022, hlm. 66-74

\begin{tabular}{|c|c|c|c|c|c|}
\hline 17 & $\begin{array}{l}\text { Tenuta et } \\
\mathrm{al} / 2015^{21}\end{array}$ & Brazil & $\begin{array}{l}\text { Titratable acidity of } \\
\text { beverages influences salivary } \\
\text { pH recovery }\end{array}$ & $\begin{array}{l}\text { Cohort (cross } \\
\text { over) }\end{array}$ & $\begin{array}{l}\text { Penelitian ini menunjukkan bahwa } \\
\text { keasaman yang dapat dititrasi dari } \\
\text { minuman mempengaruhi nilai pH } \\
\text { saliva setelah minum minuman asam } \\
\text { lebih dari pH minuman. }\end{array}$ \\
\hline 18 & $\begin{array}{l}\text { Sardana et } \\
\text { al/2012 }\end{array}$ & India & $\begin{array}{l}\text { Impact of a modified } \\
\text { carbonated beverage on } \\
\text { human dental plaque and } \\
\text { salivary pH: aAn in vivo study }\end{array}$ & $\begin{array}{l}\text { Randomized } \\
\text { controlled trial }\end{array}$ & $\begin{array}{l}\text { Modifikasi minuman uji dengan } \\
\text { konsentrasi fluorida dan fosfat yang } \\
\text { rendah mampu menurunkan potensi } \\
\text { kariogenik minuman tersebut namun } \\
\text { tidak sepenuhnya menghilangkan. }\end{array}$ \\
\hline
\end{tabular}

